„Bohemistyka” 2020, nr 3, ISSN 1642-9893

Aleksandra PAJĄK

DOI: $10.14746 /$ bo. 2020.3 .3

Uniwersytet Opolski

\section{Kreacyjna zabawa z konwencją w Listach Michala Šandy do/i Karla Havlíčka Borovskiego}

Keywords: letter, correspondence, convention, creation, bee, postmodernism, Karel Havlíček Borovský, Michal Šanda

Słowa kluczowe: list, korespondencja, konwencja, kreacja, pszczoła, postmodernizm, Karel Havlíček Borovský, Michal Šanda

\section{Abstract}

The subject of analysis is a small book by Michal Šanda (1965) Dopisy (2009). In the book the contemporary writer enters into a correspondence dialogue with Karel Havlíček Borovský (1821-1856). He creatively uses the authentic letters the Czech publicist sent from Brixen to his brother František and intertwines them with a six-month account of his life described in the convention of magical realism. By using the scrabble theme and the principle of "rewriting", Šanda creates a multi-layered system of references, which includes, for example, a place for Ernest Hemingway. This peculiar double voice, formally maintaining the convention of epistolographic discourse, becomes a contribution not only to reflections on bee breeding (the only thread that clearly links the two correspondents), but also on the role of literature.

Przedmiotem analizy jest niewielka książka zatytułowana Dopisy / Listy (2009) współczesnego pisarza Michala Šandy (1965), w której autor nawiąuje korespondencyjny dialog z Karlem Havlíčkiem Borovskim (1821-1856). Kreatywnie wykorzystuje w tym celu autentyczne listy, jakie czeski publicysta wysyłał z Brixen do brata Františka i splata je z półroczną relacją ze swojego życia opisywaną w konwencji realizmu magicznego. Dzięki wykorzystaniu motywu gry w scrabble oraz sięgnięciu po zasadę „ponownego napisania”, Šanda tworzy wielowarstwowy system odniesień, w którym znajdzie się m. in. miejsce dla Ernesta Hemingwaya. Ten swoisty dwugłos, zachowujacy formalnie konwencje dyskursu epistolograficznego, staje się przyczynkiem nie tylko do rozważań na temat hodowli pszczół (jedyny wątek wyraźnie łączący obu korespondentów), ale również o roli literatury.

W literaturze czeskiej przełomu XX i XXI wieku można odnaleźć sporo tekstów, które nawiązując do istotnego dla kształtowania się nowoczesnego modelu kultury „długiego wieku dziewiętnastego” traktują go jako przestrzeń do literackich eksperymentów czy też jako bazę do ponownego przepisywania. Tendencja ta jest bardzo wyraźna w tetralogii Ten, který bude Vladimíra Macury (1999), specyficznej powieści Václava Vokolka Cesta do pekel (1999), której swobodna kontynuacja Dominový efekt ukazała się w roku 2018, w niektórych utworach Miloša Urbana, jak Poslední tečka za Rukopisy (1998) czy Hastrman (2001), przypomniany niedawno dzięki obsypanej nagrodami adaptacji filmowej (reż. Ondřej Havelka), wreszcie w szeregu dalszych (więcej: Pająk 2017).

Oprócz tego typu literackich nawiązań ukazuje się także wiele rei edycji korespondencji ikon tego okresu, co z jednej strony oznacza, iż epistolografia pozostaje wdzięcznym tematem badawczym ${ }^{1}$, ale stanowi również odpowiedź na oczekiwania czytelnicze ${ }^{2}$. Jak zauważa Małgorzata Czermińska ,zainteresowanie dla listów autentycznych, przede wszystkim listów intymnych, listów-wyznań, zbiega się z psychologizacją, z hasłem zwrotu do wnętrza, głoszonym przez powiéść" od początku XX wieku [w oryginale „od lat siedemdziesięciu” A.P.] (Czermińska 1975, s. 32).

Korespondencja osób odgrywających znaczącą rolę w przeszłości staje sie niejednokrotnie materiałem do podejmowania kolejnych, literackich prób oddania specyfiki postaci, której historyczny prototyp żył w danej epoce, o czym niektórzy $\mathrm{z}$ autorów informują w różnego rodzaju paratekstach czy dziennikach prowadzonych paralelnie z powstajacym dziełem literackim itp. ${ }^{3}$ Tego typu strategie pisarsko-czytelnicze mieściłyby się zapewne w ramach zachowań konwencjonal-

${ }^{1}$ Zob. w odniesieniu do interesującego mnie tutaj Karla Havlíčka Borovskiego, np.: Pokorná 2016; Rychnovská, Adam 2016; Macurová, Janáčková 2016; Havlíček Borovský 2016-2018.

${ }^{2}$ W tym kontekście wspomnieć można poza Havlíčkiem kolejną edycję korespondencji: Němcová 2003-2007.

${ }^{3}$ Por. Deník Lenky Lagronové zawierający ostrą ocenę korespondencji Němcovej, czytanej na potrzeby stworzenia sztuki, której główną bohaterką była autorka Babuni (Lagronová 2016, s. 76-82). 
nych, podobnie jak samo zjawisko wydawania epistolografii, choćjak zauważa badacz małych form literackich Jan Trzynadlowski zbiór korespondencji to „fakt zarazem i konwencjonalny, i - filozoficzny, ponieważ zupełnie «naturalne» składniki funkcjonują w zasadzie jako specyficzny conceptus mentis" (Trzynadlowski 1977, s. 91).

Przedmiotem mojego zainteresowania stał się zatem tekst, w którym punktem wyjścia są XIX-wieczne listy, powstałe dla autentycznej korespondencji (Czermińska 1975, s. 28), ale stanowią one jedynie pretekst do podjęcia kreacyjnej zabawy nie tylko z konwencją ars epistolandi. Jest to ksiażeczka zatytułowana Dopisy (Havlíček Borovský, Šanda 2009). Prezentuje, idąc za informacją w niej zawartą, oryginalne teksty Karla Havlíčka Borovskiego, jakie wysyłał z Brixen do brata Františka do Německiego Brodu ${ }^{4}$. Okres internowania można uznać za prymarna konsytuację, czyli odpowiednia sytuację sprawcza (Trzynadlowski 1977, s. 83) dla zainicjowania i zaistnienia faktu pisania. W wydaniu listów kolejnej, emblematycznej postaci czeskiego odrodzenia narodowego nie byłoby zapewne nic dziwnego, wszak tego typu publikacje - jak było wspomniane - pojawiają się dość konsekwentnie. Niemniej od razu zaczyna się pole eksperymentowania, gdyż publikacja nie zawiera odpowiedzi brata, ale na okładce znajdziemy oprócz nazwiska autora Elegii tyrolskich drugie - współczesnego poety, prozaika i dramaturga - Michala Šandy (ur. 1965)

List, z reguly stanowi gatunek mocno skonwencjonalizowany ${ }^{6}$. Mowa tu przede wszystkim o liście jako formie, której główną i pry-

${ }^{4}$ Paratekst na przedostatniej stronie publikacji: „Dopisy uveřejněné v této knize jsou autentické. Původním adresátem byl ovšem bratr František” (Havlíček Borovský, Šanda 2009, s. 135).

${ }^{5} \mathrm{Na}$ okładce książki dochodzi zresztą do nieoczekiwanego zbliżenia w czasie obu autorów. W niektórych datach z życia Borovskiego pojawiają się lata 19... . Dzięki temu staje się on przynajmniej na papierze niemal rówieśnikiem Šandy. Podobnie zresztą dzieje się w treści jednego z przytoczonych listów (Havlíček Borovský, Šanda 2009, s. 73). Nie odnosi się to jednak do datacji umieszczanej na początku każdego z nich, o czym będzie jeszcze mowa.

${ }^{6} \mathrm{~W}$ badaniach teoretycznoliterackich często używana jest fraza „konwencja epistolograficzna”. Zob. np.: Całek 2019, Skwarczyńska 2006 (1937), Kosmalska 2017. marną cechą jest funkcja użytkowa, a wliczanej przez Stefanię Skwarczyńską do tzw. literatury stosowanej (Skwarczyńska 1937, 2006.). Odnosząc się do tychże badań, Anita Całek - autorka najnowszej obszernej monografii - wyraźnie eksponuje (w czwartym z sześciu paradoksów opisujących gatunek) interesujące mnie tutaj zjawisko i pisze, iż [1]ist pozostaje jako wypadkowa dwóch antynomicznych sił: rygoryzmu konwencji epistolarnych danej epoki i środowiska a inwencji oraz twórczego podejścia nadawcy" (Całek 2019, s. 77). Można również przypomnieć w tym kontekście, iż mniej więcej do połowy XIX wieku istniały „listowniki”, ,sekretarze” zawierające czy ogólne reguły, czy wręcz wzory (Czermińska 1975, s. 29), co potwierdza tezę o silnie skonwencjonalizowanym genetycznym charakterze tego typu tekstów.

Warto zatem przyjrzeć się bliżej, w jaki sposób autentyczna korespondencja została wykorzystana do podjęcia specyficznego dialogu pomiędzy rzeczywistością połowy XIX wieku a początkiem XXI i odpowiedzieć na pytanie, czy eksperyment ten powiódł się? Towarzyszyć tym rozważaniom będzie refleksja, na ile współczesny autor łamie konwencję $\mathrm{w}$ tej kreacyjnej zabawie $\mathrm{z}$ oryginalnymi epistołami. W części pierwszej artykułu skoncentruję się na głównie na stronie formalnej, w drugiej zaś skupię się na treści „odpowiedzi” Michala Šandy, gdyż to właśnie u niego wyraźnie dostrzec można żywioł kreacji i swoistego przełamywania konwencji.

W mniejszym stopniu uwagę kieruję również w stronę oryginalnych tekstów Havlíčka, będacych bodźcem dla współczesnego „odbiorcy”, a jednocześnie „,korespondenta”, Zasygnalizuję jedynie, iż wbrew wcześniej cytowanemu paratekstowi, Šanda dokonywał ingerencji w zachowaną epistolografię. Porównanie z wydaniem z roku

7 Jak zauważa Magdalena Pokorná jedyny kompleksowy zbiór korespondencj Havlíčka wyszedł w 1903 roku dzięki Ladislavowi Quiosowi. XX wiek przyniós kilka fragmentarycznych lub tematycznych wydań. Badaczka, będąca w zespole przygotowującym nową edycję w Wydawnictwie Lidové noviny (Pokorná 2016, s. 22) słusznie konstatuje, iż ,[k]orespondence je přitom významným pramenem nejen pro poznání historie, ale i pro poznání dobového jazyka či dobových norem 
$1887^{8}$ (Havlíček Borovský 1887) pozwala na lakoniczne wyliczenie zastosowanych przez niego strategii, które polegały na: modyfikacji zwrotów do adresata i podpisów, nieprzytaczaniu wszystkich następujących po sobie epistoł, niewielkich zmianach w treści (np. inicjały V.Ž. [Václav Žák] zamienione na I.W. [Ivan Wernisch]), kompilacjach $\mathrm{z}$ różnych listów, modyfikacji datowania czy pominięciach $\mathrm{w}$ odniesieniu do zawartości (np. skrócenie wątku produkcji i sprzedaży oleju) lub wobec materiału ilustracyjnego (np. brak oryginalnego szkicu polecanego bratu ula) itp. Szczegółowy opis ingerencji współczesnego autora będzie przedmiotem osobnej analizy.

Pierwszy z wykorzystanych przez Šandę listów Borovskiego został napisany 25 sierpnia 1852 roku, ostatni na sylwestra roku 1854 , wszystkie (łącznie dwadzieścia dziewięć) są w identyczny sposób datowane z podaniem miejsca pobytu nadawcy (przykładowo: „Brixen 23/7/1854"). Dłuższy okres, w jakim zamyka się całość skierowana prymarnie do brata, mógłby wskazywać, iż nie była to korespondencja bardzo obfita, a na początku również nieregularna (z roku 1852 pochodzą jedynie trzy listy, z 1853 - sześć, dopiero w ostatnim roku zdecydowania wzrasta). Znów jednak należy przypomnieć, iż Šanda nie przytacza kompletnego zbioru, dokonując nawet w tych przywoływanych tekstach pewnych manipulacji i ingerencji.

Współczesny pisarz ,odpowiada” na nie pomiędzy 8 kwietnia a 16 października 2008, co wyraźnie wskazuje na większą częstotliwość, gdyż on również „wysyła” 29 listów, wszystkie (z jednym wyjątkiem, ale jedynie sugerowanym, iż pieczątka na znaczku jest hiszpańska) teoretycznie z Pragi. Idąc dalej tym tropem, warto zatrzymać się jeszcze nad tym, co przywoływany już badacz nazywa sformalizowanym „wystrojem gatunkowym” listu (Trzynadlowski 1977, s. 83),

jazykové komunikace. Její význam pro zkoumání padesátých let 19. století, kdy jen velmi omezeně fungovaly spolky a jiné instituce sdružující občany, je ještě všestrannější“ (Pokorná 2016, s. 6)

${ }^{8}$ Za pomoc w dotarciu do oryginalnej korespondencji Karla Havlíčka Borovskiego i jej udosteppnienie dziękuję doktor Annie Gnot z Ústavu pro českou literaturu Akademie věd České republiky. obejmującym prawie wyłącznie konstrukcję tekstu, nie sięgając natomiast na razie w głąb struktury. $Z$ pewnością do tego rodzaju wyznaczników zaliczyć można oprócz datacji, zwrot do adresata, formuły końcowe, podpis, ewentualnie dopisek ${ }^{9}$. O ile w treści można odnaleźć sporo elementów wielopoziomowej gry z oryginalnym tekstem, a także ze współczesnym czytelnikiem, o tyle tutaj Šanda dość konsekwentnie trzyma się konwencjonalnych reguł obowiązujących w sztuce korespondencji. XIX-wieczny publicysta wszystkie listy poprzedza zwrotem „Milý prŕiteli” (w oryginale dominowały zwroty „Milý Bratře!”). Wpisując się w konwencję, jego adwersarz 28 razy posługuje się wołaczem „Drahý př́teli”. Raz krótki list (właściwie zawierający jeden akapit pełen wulgarnych inwektyw) rozpoczyna się dość zaskakująco: „Gaunere proradnej!” (Havlíček Borovský, Šanda 2009, s. 97), przy czym w kolejnym autor usprawiedliwia się, że został „wysłany” przypadkowo, oryginalnie był skierowany do zupełnie innego adresata ${ }^{10}$.

Przyglądając się z kolei formułom końcowym, podpisom i nielicznym dopiskom (NB), łatwo zauważyć, iż nie wykraczają one z reguły poza tradycyjne ramy. W przypadku podpisów Borovský (przytaczany przez Šandę) używa skrótów w różnych kombinacjach: Tvůj H. B., H. B., Tvůj H., Tvůj upř́imný K., K., Tvůj K, co z reguły pokrywa się $\mathrm{z}$ oryginałami (poza pominięciem określenia bratr). Gdy jednak pod tym kątem analizujemy strategię Šandy, wyraźnie zwraca uwagę jego kreatywność, nieoczekiwana w tak banalnym miejscu, jakim jest sygnatura. Do najczęściej używanych należą warianty inicjału imienia:

9 Anita Całek za Anną Kłakowską pisze w tym kontekście o wewnetrznej spójności, „która ma cechy strukturalne i zawiera się w takich elementach, jak: system konwencjonalnych formuł powitalnych i pożegnalnych (formuły terminalne wyznaczające granice tekstu); nawiązanie do korespondencji (podziękowanie za list adresata, odpowiedź na konkretną kwestię tam zawarta, przeprosiny za milczenie), prośby i polecenia, pytania, upewnienia; powiązanie członów listu i stosowanie formalnych wskaźników spójności; powtórzenia i paralelizmy (stanowiące nawiązanie do tradycji retorycznej)" (Całek 2019, s. 94-95).

${ }^{10}$ Wpisuje się on jednak w konstruowany ciąg przyczynowo-skutkowy, co mogłoby wskazywać również na inne rozwiązanie. 
(M., m., Tvůj M.) korespondujące z używanymi przez Havlíčka i wskazujące na rosnącą familiarność eksponowaną przez nadawcę. Kilkakrotnie stają się one jednak elementem zabawy literackiej, tworząc specyficzne słowne konstrukcje:

List 6. (s. 31): Šup do ní [schránky A.P.] s tímhle dopise-

List 7. (s. 36): S úklonou tvůj

Herbert von Včelojan

em.

List 9. (s. 44): V mobilu mi zavrněla esemeska od Hakla, jestli nepohnu prdelí, že půjde do té hospody sá-

m.

List 13. (s. 65): Snad ano, nicméně já lasagne ŕ la Neapol nevaŘ́m

List 23. (s. 104): Přímka v sobě podle nich [Číňanů - przyp. A.P.] nese negativní energii. Souhlasí-

List 27. (s. 122): :-) M.

List 29. (s. 132): Sbohe-

$\mathrm{m}$.

Zestawienie wskazuje, że podpisy często nawiązuja do formuł końcowych, a te również w przypadku Šandy są bardziej oryginalne niż u Borovskiego, który zresztą używał ich rzadko. Strategię zabawy $\mathrm{z}$ inicjałem imienia można powiązać $\mathrm{z}$ wątkiem gry $\mathrm{w}$ scrabble, mocno akcentowanym w listach współczesnych, o czym jeszcze będzie mowa. Natomiast jedyny pełny podpis, swego rodzaju pseudonim, (list 7) poprzedzony archaicznym zwrotem, sygnalizuje kolejne, istotne motywy. W tej depatetyzującej epistole Šanda jednoznacznie wskazuje na fikcyjność prowadzonej korespondencji (choć paradoksalnie tylko tutaj bezpośrednio reaguje na prośby o wsparcie finansowe, które Borovský w listach do brata ponawiał):

K tvým výčitkám ti povím následující: nic jsi ode mne dostat nemohl, protože jsem ti nic neposílal. Uvědom si, že není moje povinnost si s tebou korespondovat. Jestli mě budeš bombardovat svýma nesmyslnými požadavkama, neuvidís ode mne už ani písmeno. Nechám tě v tom tvém Brüxenu vysedávat $u$ Elefanta, dloubat $v$ nose a smrkance lepit zespoda pod židli. Vím, že to děláš, a neptej se od koho. [...]

S úklonou tvůj Herbert von Včelojan (Havlíček Borovský, Šanda 2009, s. 35-36).

Przytoczony fragment ewidentnie nawiązuje konkretny dialog z tekstem oryginalnym, gdyż Šanda odnosi się zarówno do ważnego wątku pszczół (właśnie w podpisie), ale także wykładu ortograficznego Havlíčka poświęconego poprawnej pisowni nazwy miasteczka, w którym ten był internowany czy częstych próśb o pieniądze. Konstruując tak wyjątkową sygnaturę, odwołuje się również do zwyczaju XIX-wiecznych „,budzicieli”, którzy tworzyli lub modyfikowali imiona i nazwiska, by brzmiały one bardziej słowiańsko, oddając jednocześnie profesję czy zainteresowania posiadacza (Macura 1995, s. 121). Parodiując tę modę, autor pozostawia jednak niemiecko brzmiące imię oraz przyimek von, co tworzy humorystyczny dysonans i wzmacnia element kreacyjnej gry ze współczesnym odbiorcą.

Zostawiając „,wystrój formalny”, można przejść do zawartości samych listów, przy czym i tutaj uwagę koncentrować będę raczej na współczesnych odpowiedziach, do tekstów Borovskiego odnosząc się jedynie marginalnie. Warto w tym miejscu postawić zapewne pytanie, czy taki specyficzny zbiór jest w ogóle koherentny, skoro obaj autorzy teoretycznie nie mają szans nawiązać dialogu? W przypadku Šandy pojawić się może uzasadnione podejrzenie o mistyfikację, ponieważ już wcześniej tego typu eksperymenty były mu bliskie (Piorecký 2016) ${ }^{11}$. On sam jednak stanowczo takie insynuacje odrzuca, dokonując interesującej charakterystyki książki:

Není to mystifikace! Jsou to prostě Havlíčkovy dopisy takové, jaké jsou, ty jsem neupravoval, nepřepisoval, a pak jsou tam dopisy moje a v podstatě na toho Havlíčka nereaguju, není to spolu vůbec pospojované. Takže bych řekl, že mystifikace to není. $\mathrm{O}$ co $\mathrm{v}$ podstatě $\mathrm{v}$ dopisech jde? Jde o to se vykecat $\mathrm{z}$ momentálních trablů, které

${ }^{11}$ Chodzi tutaj przede wszystkim o publikację Blues 1890-1940, gdzie autor wcielił się w rolę redaktora i leksykografa wydajacego znaleziony materiał archiwalny, w efekcie czego powstał leksykon poświęcony artystom pochodzacym z okolic Missisipi. Luźno z tą książką związane są również kolejne, z których pierwsza nosi intrygujący tytuł Obecní radni Stoklasné Lhoty vydraživš́i za 37 Kč 
člověk má. A to máte jedno, jestli píšete Havlíčkovi nebo bratrovi. Jsou to v podstatě dvě na sobě naprosto neodvislé, paralelní linky (Faltýnek 2016 ) ${ }^{12}$.

Czy faktycznie jednak jest tak, jak opisuje to autor? Pierwsze wrażenie potwierdza powyższą ocenę, choć - jak już było wskazane - nie do końca prawdziwa jest konstatacja mówiąca o braku ingerencji w oryginalne listy. Gdy pochylimy się nad tekstami głębiej, okaże się, że kilka powiązanych wątków Šanda nieco zakamuflował i tutaj więc nie do końca można mu wierzyć. Wspomniana była jednorazowa reakcja w kwestii finansowej. O wiele bardziej łącznikiem między obu korespondentami wydają się być pszczoły, w czym zresztą czytelnika utwierdza szata graficzna. Owady te są wszechobecne, zarówno na okładce, jak i na stylizowanej ilustracji na stronie tytułowej, której dominantę stanowi rój, oddając tym samym proporcje, jakie są zachowane w treści. Nie dzieje się tak z pewnością przypadkowo z kilku co najmniej powodów: Michal Šanda jest pszczelarzem-amatorem (informacja od Ivo Haráka), ale - co z pewnością istotniejsze - sam obiekt zainteresowania zarówno $\mathrm{w}$ mitologii, a potem również w kulturze tradycyjnej uważany jest za stworzenie boskie i święte (Cooper 1998, s. 219; zob. też: Łeńska-Bąk 2016). Sądzono wręcz, że pszczoła

[...] pochodzi z nieludzkiego obszaru sacrum, i w związku z tym posiada właściwości charakterystyczne dla tego, co znajduje się na Tamtym Świecie. [...] chtoniczna

vycpaného jezevce pro potřeby školního kabinetu oraz Sudamerická romance (Kronika osidlování Gran Chaca). Ich łącznikiem pozostaje - oprócz mistyfikacji - usytuowanie narracji w początkach XX wieku (Piorecký, on-line).

Lenka Poř́zková z kolei uważa, że Dopisy to modyfikacja mistyfikacji korespondencyjnej; oba typy dokumentów sa autentyczne, choć w przypadku Šandy trzeba zwrócić uwagę na stopień stylizacji oraz ,udawaną formę korespondencyjną”. Ich połączenie stanowi całość tworzącą groteskowy, ale wysoce literacki, tj. wykreowany gest (Pořízková 2014, s. 200-201). Badaczka pomija jednak ingerencje współczesnego autora w oryginalne teksty Borovskiego.

${ }^{12} \mathrm{~W}$ samym tekście znajdziemy również tego rodzaju metatekstową aluzję: „Kdekdo mě nabádal, abych se od realismu vrátil k mystifikacím, jenomže literatura je riskantní záležitost a opakovat osvědčené postupy je proti jejímu smyslu. Říká se tomu jít neprošlapanou cestou" (Havlíček Borovský, Šanda 2009, s. 81). natura lokuje ją na granicy między światami śmiertelników i bogów. Pszczoła mogła więc spełniać funkcje posłańca i pośrednika między człowiekiem a bóstwem (Kowalski 1998, s. 468).

Warto także zwrócić uwagę, iż owady te stają się współcześnie coraz częstszym bohaterem nie tylko licznych poradników, które (wobec groźby wyginięcia pszczół zapowiadającego kres ludzkości) propagują modę na zakładanie pasiek czy wysiewanie roślin miododajnych nawet $\mathrm{w}$ mieście, ale także literatury fabularnej. Wystarczy wspomnieć przykładowo bestsellerową powieść Mai Lunde Historia pszczót (Lunde 2016). Choć przesłanie, wymowa, poetyka pierwszej z klimatycznego cyklu książki skandynawskiej pisarki są zgoła odmienne od zabawy czeskiego autora, to jednak warto podkreślić, iż oba utwory sa przykładami literackiej kariery owadów od wieków stanowiących ważny element europejskiego imaginarium (Łeńska-Bąk 2016).

Dzięki eksperymentowi Šandy pszczoły zatem łączą dwa w rzeczywisty sposób niemożliwe do połaczenia światy oddalone od siebie temporalnie. W przypadku Havlíčka ich hodowla, marzenie o własnej pasiece stanowić miały odskocznię od dnia codziennego, a jednocześnie sposób na zabicie nudy, na którą wielokrotnie narzekał. Oryginalny adresat, posiadajacy pare uli, jest przez brata nieustannie pouczany, gdyż Borovský zgłębia tajniki pszczelarstwa na podstawie dostępnej mu, choć ograniczonej, literatury poradnikowej. A propos pszczelarskich zainteresowań Havlíčka czytelnika może zaintrygować powracająca ocena prac prekursora naukowego podejścia do hodowli tych owadów - Jana Dzierżona ${ }^{13}$ (1811-1906) określanego już w połowie XIX w., a więc mniej więcej w czasie, w którym czytał je-

${ }^{13}$ Dzierżon pojawia się także epizodycznie w Historii pszczót Mai Lunde, dokładnie w opowieści Williama Savage'a, XIX-wiecznego przyrodnika i konstruktora rewolucyjnego ula, który nieco spóźnił się ze swoim wynalazkiem. Wiliam jest jednym z trojga narratorów monumentalnej całości. Drugie, współczesne opowiadanie (akcja rozgrywa się w 2007 roku w Stanach Zjednoczonych) snuje George, właściciel rodzinnej pasieki, który musi zmierzyć się z początkiem masowego wymierania pszczół. Całości dopełnia postapokaliptyczna wizja świata bez tych życiodajnych stworzeń, którą słyszymy z ust Tao, mieszkanki Syczuanu w roku 2098. 
go prace Havlíček (prenumerował w tym celu czasopismo) jako ,[a]rcymistrz pszczelarstwa, Altmeister Bienenzucht, der grosse Bienenvater, Ojciec pszczelnictwa postępowego" (cyt. za: Baj 2006). Autor Elegii tyrolskich nie ma jednak dla dokonań Dzierżona zrozumienia i wielokrotnie podaje w wątpliwość czy wręcz dezawuuje jego obserwacje, posługujac sie konsekwentnie zniemczona wersja jego nazwiska. Wobec niezaprzeczalnych zasług zwłaszcza na polu naukowych odkryć dotyczących partenogenezy pszczół oraz budowy tzw. ula ramkowego, który mocno krytykuje Havlíček, jego uwagi mogą być postrzegane jako wyraz konserwatywnych poglądów w tej kwestii i ostrożności wobec nowych osiągnięć na tym polu.

Motyw pszczół, obok doraźnych kłopotów z wynajęciem mieszkania, próśb o przesłanie konkretnych rzeczy czy pieniędzy, informacji o żonie Julii, córce Zdence, jest zdecydowanie jednym z wyraźniejszych w oryginalnych XIX-wiecznych listach (zwłaszcza biorąc pod uwage, że inne „ekonomiczne” eksploracje Šanda niemal całkowicie pomija i ich nie przytacza). Narzekający na brak pieniędzy Havlíček, szuka praktycznych sposobów na ich zdobycie i nieraz kreuje się na znawcę ekonomii. Stąd oprócz pasieki, marzy mu się np. eksport oleju z Czech, na którym by można nieźle zarobić czy narzeka na drogie zabawki. Wątki te są jednak zdecydowanie zminimalizowane w wersji cytowanej przez współczesnego pisarza. Pszczele rozważania urozmaicają zatem sprawozdawczą część autentycznej korespondencji, pozostając w dużej mierze w sferze planów na przyszłość (jak wiemy z biografii autora, niezrealizowanych).

I to do nich nawiązuje w pełen kreacji sposób Šanda. Prowadząc właściwie specyficzny dziennik (Pořízková 2014, s. 200), oddający własne refleksje i wydarzenia prywatne w przeciągu awizowanego półrocza, opisuje w konwencji realizmu magicznego przybycie do swego praskiego mieszkania bezimiennej, puszystej kobiety (org. boubelatážena). Z jej szminki rodzi się pierwsza pszczoła, która daje następnie za pomocą lustra ${ }^{14}$ (,Zanedlouho navzájem se zrcadlící zrcadla udělala ze rtěnkové včely mnohočetný roj" [Havlíček Borov- ský,

${ }^{14} \mathrm{O}$ roli lustra w kulturze zob.: Lukavec 2010.
Šanda 2009, s. 16]) początek całej rodzinie, ta zaś zasiedla stojącą w pokoju komodę.

Ten niecodzienny sposób przyjścia na świat owadzich lokatorów sugeruje, iż pisarz hojnie będzie sięgał do rezerwuaru postmodernizmu, gdzie zwierciadło (obok wielu innych, jak biblioteka, labirynt, podróż bez celu i przeznaczenia, reklama, telewizja, fotografia, prasa, paranoja, przemoc i pornografia) ${ }^{15}$ stanowi jeden z leitmotywów. Obserwacje pszczelich zwyczajów przeplatają się z pamiętnikarskimi zapiskami z życia pisarza Michala Šandy, a zarazem partnera tajemniczej, bezimiennej rzeźniczki. W linii realistycznej, mocno autobiograficznej, przywołuje on np. wieczór autorski, gdzie prezentował własny tomik Kecanice, wielokrotnie pisze o czasopiśmie „Dobrá adresa" "16, w którym w 2008 roku prowadził rubrykę Z antikvárnich banánovek, gdy redaktorem naczelnym był również wspominany w listach Štefan Švec. Często wzmiankuje innych współcześnie żyjących pisarzy, jak Emil Hakl, Vít Kremlička, Ivan Wernisch (w listach w roli piekarza i właściciela cegielni), także związanych z periodykiem. Jednocześnie nieraz podkreśla, a nieraz podaje w wątpliwość sens nie tylko swej profesji. W momencie, gdy jego partnerka życiowa, jak czytamy w liście 19, chce poznać przeszłość człowieka, z którym mieszka, ten każe jej jednak czytać własne publikacje. Następnie ironicznie zauważa, iż na rzeźniczce największe wrażenie wywarł tomik Dvacet deka ovaru. Trudno oprzeć się doznaniu, iż nawet to nie jest bez znaczenia. Wielokrotnie powracający wątek specyficznej pasji, a jednocześnie profesji bohaterki może wywoływać skojarzenia ze znaną sceną świniobicia z Postrzyżyn Bohumila Hrabala, do którego również o wiele bardziej czytelnie autor nieraz się odnosi. W jednym miejscu wręcz eksponuje inną scenę ze wspomianego utworu:

Včely byly všude, všechno se vlnilo a přeskupovalo. [...] Potom se naráz zvedly a utvořily obrovitý hrozen kroužící bytem. Boubelatá žena duchapř́tomně zabouchnula okno. Neumím si představit, kdyby roj uletěl. Třeba na komín. Obzvlášt' vysoký

\footnotetext{
${ }^{15}$ II i III asyndeton Douwe'a Fokkemy. Zob.: Janaszek-Ivaničková 2002, s. 91.

16 Wszystkie numery tego interesującego czasopisma dostępne są tutaj: http://www.dobraadresa.cz/old.htm [23.08.2019]
} 
komín zůstal trčet po zbouraném libeňském pivovaru. Lézt na něj a sbírat roj, nařknuli by nás přihližející čumilové, že s boubelatou ženou plagiujeme Hrabala. Pivovarský komín má provždy propachtovaný on a vystup na něj je zase ta jedinečná scéna, která ulpěla čtenářům z Postřižin (Havlíček Borovský, Šanda 2009, s. 75).

Hrabalowski wątek powraca również pod sam koniec wymiany listów. Znaczną część przedostatniego tekstu współczesnego korespondenta zawiera przywołana w cytacie scena świniobicia (Havlíček Borovský, Šanda 2009, s. 126-128), z kolei w nastepnym - stylizowanym nieco na literacki testament - aluzyjnie odnosi się do samobójczej śmierci autora Pociagów pod specjalnym nadzorem, metaforycznie winiąc za to literaturę (Havlíček Borovský, Šanda 2009, s. 131).

Wracając jednak do kluczowego wątku - Šanda definiuje współtworzony przez siebie i Borovskiego utwór jako ,korespondenční kniha rojení" (Havlíček Borovský, Šanda 2009, s. 74), przywołując jedno z kluczowych w pszczelarstwie zjawisk, ,opisane” także w powyższym przytoczeniu. Czytelnik ma wrẹcz momentami wrażenie, że listy współczesne roją się nie tylko dosłownie, ale przede wszystkim metaforycznie od różnych tematów, począwszy od opisów czynności naturalnych i codziennych, a skończywszy na tych zupełnie nierealnych, jak rój pszczeli towarzyszacy parze podczas śniadania, a następnie dostarczający rozrywek seksualnych, służący jako narzędzie do pomalowania mieszkania, produkujacy miód z kwiatów umieszczonych na plakacie do filmu $O$ rodičich a dětech (na podstawie książki Hakla). Tutaj także przynależy m. in. zawarty w liście 6 . opis podróży do nieżyjącego już XIX-wiecznego prekursora pszczelarstwa Balka $\mathrm{z}$ Moníce, jaka para podejmuje, a który był wspominany w oryginalnych epistołach przez Havlíčka.

Jak widać - wbrew wcześniejszej autorskiej ocenie - listy nie rozchodzą się jednak zupełnie, a raczej Šanda posługuje się nieraz zabiegami zwielokrotnienia (multiplication) i przemiany (permutation), typowymi dla postmodernizmu (Janaszek-Ivaničková 2002, s. 91). Przykładem może być choćby wspomniany mebel, pełniący de facto rolę miejskiego ula. O jego pochodzeniu z Kampy dowiaduje się czytelnik z obszernej relacji w liście 3., po jakimś jednak czasie, okazuje się, iż wzmiankowany już redaktor Švec ma wrażenie, że należała do jego ciotki. Wyrafinowany zabieg czytelny jest w pełni dopiero, kiedy w tekście Borovskiego, cytowanym przez Šande (datowanym na 15/7/1854) znajdziemy aluzję do komody:

Bude-li podzimek př́znivý, můžeš odebrati ještě brzy před zimou jeden pletenec a aby byly přinuceny založiti si hnízdo v Hubrově oulu. Doufám, že to dobře půjde, a těším se na tvůj referát, neb myslím, že tě pak manipulace s tím Hubrovym oulem mnohem vice těšiti bude než s komodou (Havlíček Borovský, Šanda 2009, s. 100$-101)$

Dla ścisłości należy dodać, iż oryginalny list, z krórego czerpał Šanda, udało się zlokalizować pod datą 8/7/1854. Zawiera on obszerny dopisek datowany $11 / 6 / 1854$, ponownie jednak widoczna jest subtelna manipulacja współczesnego autora-edytora, którą zdemaskować może tylko dokładna komparacja obu tekstów. W oryginale bowiem słowo komoda nie występuje, a inkryminowany fragment brzmi:

Doufám, že to dobře půjde, a těším se na tvůj referát, neb myslím, že tě pak manipulace s tím Hubrovym oulem mnohem vice těšiti bude než se slaměnáky (Havlíček Borovský 1887, s. 124).

Niemniej współcześnie mebel to miejsce, w którym pracowite owady produkują miód, traktując ubrania jako ramki. $Z$ kolei w kilku co najmniej listach Borovskiego zawarte są liczne wskazówki na temat prawidłowej budowy ula jako punktu wyjścia dla przynoszącej zysk pasieki. Oryginalny list z 3 września 1853 roku zawiera nawet szkic (Havlíček Borovský 1887, s. 53), który jednak nie został skopiowany w wydaniu współczesnym, co może nieco dziwić, gdyż w swojej części Šanda kilka elementów graficznych umieszcza. System odniesień jest jednak o wiele bardziej skomplikowany. Ule w celu łatwiejszej identyfikacji Havlíček proponuje nazywać inicjałami, domagając się drobiazgowych relacji na temat ich zawartości i prowadzac specyficzna buchalterię. To być może stało się bodźcem do podjęcia wątku zabawy literami i we współczesnych listach, gdyż współmieszkańcy pszczelego gospodarstwa często graja we wspomniane scrabble. Częścią 10. listu Šandy staje się przerysowana plansza. Wskazuje ona parokrotnie na pszczele asocjacje i stanowi niejako instrukcję i zapowiedź tego, co nastąpi w życiu specyficznej pary. 
Tabela 1. Scrable; za: Havlíček Borovský, Šanda 2009, s. 47

\begin{tabular}{|c|c|c|c|c|c|c|c|c|c|c|c|c|}
\hline & & & & & & & & V & C & E & L & A \\
\hline & T & A & F & L & O & V & A & N & I & & & T \\
\hline & & & I & & & & & E & & & & R \\
\hline & & & L & & & S & & & & & & O \\
\hline B & & & C & H & Y & T & I & & & & & P \\
\hline U & & & K & & & O & & & & K & & I \\
\hline R & O & J & A & C & E & K & & B & & L & & N \\
\hline G & & & & & R & Y & B & A & R & I & T & \\
\hline U & & & & & B & & & R & & K & & \\
\hline E & T & N & O & L & O & G & & B & R & A & K & Y \\
\hline T & & & & & V & & & A & & & & \\
\hline E & & & & & N & & & R & & & & \\
\hline & & & & & I & & & K & & & & \\
\hline & & & & & M & E & D & O & M & E & T & \\
\hline
\end{tabular}

Zabawa słowami również wpisuje się w konwencję realizmu magicznego, gdyż tworzone wyrazy przenoszą graczy w świat konkretnych utworów literackich. Klamka (klika) ,otwiera” tekst, do którego podpowiedź stanowi jedyna nazwa własna ułożona w pierwszej pionowej kolumnie. Burguete oraz czasownik rybařit (8 wers poziomo) „zapowiadają, iż podróż zakończy się w fabule powieści Słońce tė̇ wschodzi Ernesta Hemingwaya. Część tego listu stanowi fragment XIII rozdziału Fiesty (pod takim tytułem utwór wyszedł w Anglii), gdzie dochodzi do utożsamienia jej 1-osobowego narratora Jake'a Barnesa z Šandą, w roli łowiącego pstrągi. Z kolei w liście 11. słowa býk i Pampeluna (ułożone w kolejnej rozgrywce) przenoszą bohaterów na kluczową w utworze Hemingwaya scenę korridy, a tekst inkorporuje znaczną część przekładu rozdziału XVIII angielskiego oryginału. Obszerny w dużej mierze dosłowny cytat, zmodyfikowany jedynie w końcowej części ${ }^{17}$, świadczy zarówno o hybrydalności, jak i otwarciu się na odmienne poetyki (Janaszek-Ivaničková 2002, s. 92). Tezę tę po-

${ }^{17}$ Bycze ucho dostaje w pierwszej wersji nie Brett (jak w oryginale), ale boubelatá žena. Dopiero wobec jej wyraźnego protestu i zarzutu kradzieży przez nią wyartykułowanego, autor zmienia ostatecznie zakończenie. twierdzają zasygnalizowane również wcześniej odniesienia do twórczości i postaci Hrabala. Z owego systemu i zasady rewriting autor doskonale sobie zresztą zdaje sprawę, a co więcej, dosłownie ją eksplikuje:

Jakmile ho [Romera przyp. A.P.] Hemingway učinil postavou Fiesty ${ }^{18}$, stal se za jeho konání odpovědný on. Já zas jsem se zmocnil Fiesty. Zatoužil jsem mít ve své knize býčí zápasy a krevnatější než Hemingway je nikdo nesvede. Fiesta se stala součástí dopisů Havlíčkovi. My dva jsme rovněž jejich součástí a dopisy jsou zase součástí Dopisư. Už ne Hemingway, nýbrž já rozhoduju, co kdo z nás udělá. Mohl bych napsat, že Romero odnesl uř́iznuté ucho do ordinace $\mathrm{k}$ otolaryngologovi, ale nechal jsem ho, aby ho hodil tobě. Myslel jsem, že ti tím udělám radost.

„Kradeš jenom v literatuře, nebo i v supermarketu?!” naprčila se boubelatá žena.

„To není krádež, to je postmoderna” (Havlíček Borovský, Šanda 2009, s. 57).

O wielowarstwowości tego systemu intertekstualnych odwołań świadczy fakt, iż w przywoływanej już autentycznej rubryce, jaką w tym czasie Šanda prowadził, zamieścił „,recenzję” publikacji Pavla Durdika Zápasy s býky (Corrida de tores). Dojmy a obrázy ze Španělska (http://www.dobraadresa.cz/old.htm; dostęp: 25.08.2019). Niedawno zaś ukazał się jego tom opowiadań Hemingwayův býk, nominowany do nagrody Magnesia Litera 2019 w dziedzinie prozy. Poprzedzony mottem z angielskiego pisarza „Literatura je k spisovateli stejně nemilosrdná jako k toreadorům korida" (Šanda 2018, s. 7), mógłby otwierać analizę tego poruszonego również w Listach wątku, gdyż Havlíček ma być także równoprawnym partnerem do dyskusji na temat statusu i kondycji literatury (choć z oczywistego względu pokładanych weń nadziei nie spełnia). Warto zaakcentować w kontek-

${ }^{18}$ Fiesta ukazała się w Anglii w roku 1926, zaś rok wcześniej w Stanach Zjednoczonych jako The Sun Also Rises (pl. Stońce też wschodzi, przeł. B. Zieliński). Uznawana za powieść z kluczem, opowiada skomplikowane relacje i perypetie kilkorga amerykańskich znajomych przebywających w Paryżu, którzy wybrali się na święta Sanfermin(es) do Hiszpanii. Oparta w dużej mierze na osobistym doświadczeniu scena korridy przejęta przez Šande jest wspominana przez biografa Hemingwaya, włacznie z podarowaniem przez torreadora żonie pisarza byczego ucha (Nagel 1992, s. 81). 
ście zoologicznych fascynacji Šandy, iż tym razem miejsce pszczół zajmują - niejako wbrew tytułowi - głównie ryby.

Wracając do fabularnego Listów - po tym, jak boubelatá žena (a więc główna postać) zakazuje pisać o sobie, pożegnalna epistoła potwierdza, że Borovský stał się niejako „,narzędziem” do rozważań na temat literatury, a Šanda ponownie nawiązuje do wcześniejszego wątku:

Literatura je nenažraná bestie. Mrštík, Neruda, Váchal, Klíma, Mahen, Šrámek, Kainar, Bezruč, Kafka, Blatný, je jich hodně, z koho vysála sílu k plození čehokoliv, kromě ní samé. [...] Za posledního tři čtvrtě roku jsem ti napsal všechno, co bylo potřeba. Mnohé jsem si přitom ujasnil o literatuře a o svém vlastním životě. [...] Dopíšu tenhle dopis a pověsím spisovatelství na hřebík. [...] Nač krmit bestie dalšími sousty. Budu hrát scrabble. V dobrém smyslu slova je scrabble pot'touchlý. Tváŕí se, jako by literaturou byl, jenomže není. Smeteš ho dlaní do sáčku, do posledního písmene. Scrabble je hra a o hru mi při mém dosavadním spisovatelském hmoždění šlo především. Pomocí scrabblu se můžeme s boubelatou ženou podívat do knih už napsaných. [...] Nevylučuju, že pokud si ze sáčku vytáhneme patřičná písmena, že se někdy v budoucnu nevrátíme i sem, přes předcházející kasání doufám, že se najde nakladatel ochotný z naší korespondence udělat knihu (Havlíček Borovský, Šanda 2009, s. 131-132)

Życzenie wyrażone na końcu tego specyficznego dwugłosu spełniło się, naruszając w dużym stopniu zasady obowiązujące przy wydawaniu konwencjonalnych zbiorów korespondencji, dodać należy.

Współczesny autor w oczywisty sposób balansuje pomiędzy tym, co Trzynadlowski nazywa zbiorem „,naturalnym” a ,wykreowanym”. Ten pierwszy odnosi się do ,listów prywatnych między określonymi osobami historycznie równoważnymi, tzn. równoważnymi w sensie uprawnień korespondencyjno-biograficznych. [...] [z]biór kształtuje się «naturalnie», niejako od środka, od istoty i charakteru listów, przy czym edytor czy badacz stoi wobec konkretnej sytuacji zastanej". Šanda, występuje jednak w podwójnej roli, bierze oryginalne listy (niczym archiwista, zbieracz czy edytor, choć - jak wiemy już - ingeruje w nie dość znacznie), ale dopisuje także jako autor współczesną część, pozostając jednocześnie tym, który „sam niejako decyduje o całościowym kształcie korespondencji, całość tę sam kreuje" (Trzynadlowski 1977, s. 88). Okazuje sie być nie tylko „późnym wnukiem”, który z zaciekawieniem sięgnął po ów pamiętnik mimo woli, in statu na- scendi (Trzynadlowski 1977, s. 96) prymarnie skierowany do współczesnego Borovskiemu adresata, ale dzięki postmodernistycznym strategiom wykorzystuje lekturę w jedyny i niepowtarzalny sposób. Wbrew autorskim zapewnieniom i mimo dystansu czasowego Šanda nawiązał specyficzny dialog ze swoim adwersarzem żyjącym ponad półtora wieku wcześniej. Dzięki podejściu pełnym kreacji ożywił teksty, które - być może - dzisiejszemu czytelnikowi nie wydawałyby się zbyt interesujące i wypełnił to, co sam zresztą zapowiedział:

Však Borovský byl taky znamenitý spisovatel a z toho mám obrovskou radost. A zase na druhou stranu já doufám, že až tohleto vyjde ${ }^{19}$, tak já udělám část práce pro Havlíčka, aby se zase po delší době připomenul něčím živým, jiným než je čítanka (Faltýnek 2016).

Autorski team dobrze się uzupełnia, a Borovský, postawiony momentami w roli psychoterapeuty, któremu można się zwierzyć, jak choćby we fragmencie: „Co mám já? Ve trriatřiceti mám za sebou osm vydaných knih. Znamenají pro mne hodně, přesto jsou to potištěné papíry" (Havlíček Borovský, Šanda 2009, s. 85-86), mimo iż pozornie nie odpowiada, spełnia swe zadanie. Jego autentyczna korespondencja, również przez przełamanie konwencji obowiązujacej edytora, stała się przyczynkiem do rozważań nie tylko o jej statusie, ale także o tym, czym jest literatura w ogóle. W specyficzny sposób koresponduje to ze spostrzeżeniem Magdaleny Pokornej, która zauważa, iż „,[s]vět Karla Havlíčka vyvstávající z jeho korespondence, publikovaných žurnalistických textů i dobových polemik by mohl hodnoty, potřebné dnešku i budoucnosti, připomínat jako stále živý odkaz evropsky inspirované osobnosti našich dějin" (Pokorná 2016, s. 6). Choć należy ponownie zaakcentować, iż Šanda używa głównie krzywego zwierciadła, by je wyeksponować

Sam fakt sięgnięcia po epistolografię ikonicznej postaci czeskiego odrodzenia narodowego i wpisanie się jej w tak specyficzny kontekst może wywołać pytanie o granice eksperymentu literackiego. Abstra-

${ }^{19}$ Wywiad był opublikowany w momencie, kiedy książka nie była jeszcze wydana, jedynie w czasopismach drukowano jej fragmenty. 
hując nieco od faktu nawiązania dialogu z tekstami dawno zmarłego autora, można przyjąć, iż wbrew regule mówiącej, że ,poszczególne składniki zbioru korespondencyjnego powstają wyłącznie dla informacji i dokumentacji bieżącej, niejako na danym etapie kontaktów międzyludzkich zamykających sprawę lub wyznaczających jej określone granice”(Trzynadlowski 1977, s. 92), współczesny autor świadomie je przekracza, łamiąc przy tym wiele obowiązujących konwencji, ale też swego rodzaju tabu kulturowych, czyniąc jednocześnie zakamuflowane nawiązania. W jednym z listów Havlíčka, poświęconych opisowi nowo wynajętego w Brixen mieszkania po wyjeździe żony i córki (list 26.), znajdziemy następujący fragment:

Mám dva hezké pokoje s pořádným nábytkem, jeden, kde bydlím, má tři okna, druhy, spací, dvě okna, ale není k topeni, oba jdou do ulice v prvním poschodí, a sice na nejhlučnějším místě v Brixenu - u kostela. Nad kastnem a zrovna na proti němu za mým psacím stolem visí na šňůrách moje knihy naproti sobě, nad divanem je veliký obraz, nad knihami, proti mému stolu visí můj mistr Hus a nad mou posteli visí též velký obraz: krom toho hezké opony ve všech 5 oknech, a máš popis celého bytu (Havlíček Borovský, Šanda 2009, s. 116).

Warto ponownie porównać przytoczenie to z oryginałem, co tym razem jest nieco łatwiejsze, gdyż faktycznie urywek ten można zlokalizować w liście tak samo datowanym. Poza stylistyczną korektą (zmiana archaizmów) trzeba odnotować, iż został nie pierwszy raz pominięty element graficzny (szkic mieszkania), który w pierwotnej wersji znajduje się mniej więcej w połowie cytatu (Havlíček Borovský 1887, s.152-153). Być może wspomniany tutaj obraz czeskiego reformatora stał się impulsem do zbudowania ciągu asocjacji. Šanda, wykorzystując żywy w okresie odrodzenia narodowego kult Jana Husa, przywiązanie do niego Havlíčka Borovskiego, które potem zresztą stało się nieraz do wysuwania między nimi paralel, podejmuje się dekonstrukcji jego mitu, posługując się strategią permutacji. W dużo wcześniejszym liście (nr 7) przytacza bowiem anegdotyczną historyjkę o sprzedawcy grillowanych kurczaków, przypominającą nieco komizm słowny ze sztuki České nebe Járy da Cimrmanna, na której końcu postać Husa czytelnie, choć nie bezpośrednio jest przywołana:
Grilovač nůžkama zamazanýma od oleje rozstřihnul kuře vejpůl. Při porcování zůstane biskup na jedné straně. Tohle kuře biskupa nemělo. [...] Ostatní kuřata otáčející se na rožních byla taky bez biskupů.

$$
\text { „Kde jsou?” }
$$

„Kdo?”

„Biskupové."

„Na koncilu,” odseknul grilovač.

Oplatil jsem trapárnu trapárnou:

„A kolem popelnice máte kostnici, k naprostý dokonalosti byste měl grilovat husy" (Havlíček Borovský, Šanda 2009, s. 116).

Taka strategia demityzacji (w tym przypadku podwójnej niejako) może ewokować wzmiankowanego na początku tego tekstu Vladimíra Macurę. Zwłaszcza Guvernantka (1997) z nieco obrazoburczym obrazem Františka Čelakovskiego i jego żony Antonii podobne opinie również prowokowała (Hoffmann 1999, s. 4). Z jednej strony zatem Šanda świadomie sięga do prywatnej korespondencji Borovskiego i z pewnościa ja ożywia, ale z drugiej również jego sylwetkę mocno „odbrązawia”. Także pod tym względem nawarstwia podobne zabiegi, co wyraźnie widać w powyższym przytoczeniu, ilustrującym fakt, iż pisarz swobodnie manipuluje wątkami zaczerpniętymi z oryginalnej epistolografii Borovskiego, traktując ją jako przyczynek do ciągu najróżnorodniejszych asocjacji. Pomysłowe wykorzystanie w tym celu listu sprawia, iż wpisuje się to w konstatacje dotyczące natury genologicznej tego rodzaju tekstów. Cytowana już parokrotnie Anita Całek, wychodząc od klasycznych rozważań Stefanii Skwarczyńskiej na temat istoty listu, zauważa (nieco polemicznie wobec przywoływanej nestorki badań), że:

[...] [1]ist mieści się [...] na linii pomiędzy literackością a użytkowością - nie realizuje żadnej z tych cech $\mathrm{w}$ absolutnym wymiarze, ale daje się umieścić na continuum, a poziom dookreślenia tej akurat właściwości może się zmieniać w danym zespole epistolarnym w zależności od sytuacji, kontekstu, celu oraz szeregu innych okoliczności formujących jego całokształt. [...] List jest bardziej lub mniej intymny (jej krańcowym zaprzeczeniem i przeciwieństwem jest otwartość oraz publiczny dostęp do treści); bardziej lub mniej skonwencjonalizowany (mieszcząc się pomiędzy pełną realizacją określonej formy a całkowitą wolnością od niej) (Całek 2019, s. 86). 
Powyższe konstatacje ilustrują niejako strategię stosowaną przez Michala Šandę, który dzięki wskazanym zabiegom przesuwa bardziej lub mniej intymne listy na linii od użytkowości ku literackości, zarówno jeśli chodzi o jego autorskie teksty (bliższe tej drugiej kategorii), ale i te ,pożyczone” od Borovskiego, które wpisuje w zupełnie nowy kontekst. Jednocześnie wypowiada się za oryginalnego adresata, uzupełniając ów specyficzny dwugłos korespondencyjny o brakujące ogniwo i wydobywa w ten sposób epistolarny byt $\mathrm{z}$ otchłani, nadając mu - wbrew upływowi czasu - drugie życie.

\section{Źródła internetowe}

\section{www.dobraadresa.cz}

www.michal-sanda.cz

www.radio.cz

www.slovnikceskeliteratury.cz

\section{Literatura}

B a j Janina, 2006, Jan Dzierżon, śląsi przyjaciel pszczót, „Pasieka”, nr 4. On-line: https://pasieka24.pl/index.php/pasieka-czasopismo-dla-pszczelarzy/74-pasieka-4-2006/760-jan-dzierzon-slaski-przyjaciel-pszczol [dostep: 19.06.2016].

C a ł e k Anita, 2019, Nowa teoria listu, Kraków: Księgarnia Akademicka.

Co o per Jean C., 1998, Zwierzęta symboliczne $i$ mityczne, przeł. A. Kozłowska-Ryś, Poznań: Dom Wydawniczy „Rebis”.

C zermińs k a Małgorzata, 1975, Pomiędzy listem a powieścia, „Teksty: teoria literatury, krytyka, interpretacja", $\mathrm{nr} 4$ (22), s. 28-49.

F a ltý n e k Vilém, 2016, Michal Šanda si píše s Borovským [wywiad]. Online: http://www.radio.cz/cz/rubrika/knihy/michal-sanda-si-pise-s-borovskym [dostęp: 16.06.2016].

Havlíč e k B orovs ký Karel, Š a nd a Michal, 2009, Dopisy, Praha: Dybbuk.

Hav líč e k B orovs ký Karel, 1887, Vybrané spisy, pořádá Karel Tůma, díl 3., Kutná Hora: Knihkupectví a knihtiskárna K. Šolce.

H a v líic e k B or ov s ký K arel, 2016, Korespondence 1831-1842, Praha: NLN. H a v lí č e k B o r o v s ký Karel, 2018, Korespondence II 1843-1844, Praha: NLN.

H e m in g w a y Ernest, 1990, Stońce też wschodzi, przeł. B. Zieliński, Warszawa: Państwowy Instytut Wydawniczy.

H o f fm a n n Bohuslav, 1999, František Čelakovský jako literární postava. Pocta Vladimíru Macurovi beletristovi, ,Tvar”, $\mathrm{nr} 14, \mathrm{~s} .4$.

J a n a z e k - I v a n i č k o vá Halina, 2002, Nowa twarz postmodernizmu, Katowice: Wydawnictwo Uniwersytetu Śląskiego.
K o s m a 1 s k a Weronika, 2017, Konwencja epistolograficzna i bezpośredniość wyrazu w listach Jana III Sobieskiego do Marysieńki, „Racjonalia”, nr 7 , s. $77-100$.

Kow als ki Piotr, 1998, Leksykon. Znaki świata. Omen, przesad, znaczenie, Warszawa: Wydawnictwo Naukowe PWN

L a g r o n o vá Lenka, 2016, Z deníku Lenky Lagronové, [w:] Eadem, Jako břitva (Němcová), Praha: Národní divadlo, s. 76-82.

Ł e ń s k a - B ą k Katarzyna, 2016, Od pszczoły mitycznej do pszczoły wspótczesnej, czyli o kuriozalnej utracie znaczeń, [w:] Świat kuriozów: od zadziwienia do fascynacji, red. K. Łeńska-Bąk, Opole: Wydawnictwo Uniwersytetu Opolskiego, s. 29-42.

L u k a v e c Jan, 2010, Zneklidňujicí svět zrcadel, Praha: Malvern.

L u n d e Maja, 2016, Historia pszczót, przekł. A. Marciniakówna, Kraków: Wydawnictwo Literackie.

M a c u r a Vladimír, 1995, Znamení zrodu. České národni obrozeni jako kulturni typ, Jinočany: $\mathrm{H} \& \mathrm{H}$

M a c u r o vá Alena, J a ná č k o vá Jaroslava, 2015, Milostné listy Karla Havlička a Fany Weidenhoffrové II. Kdojsem já?, „Česká literatura”, nr 5, s. 204-224.

M a c u r o vá Alena, J a n á č k o vá Jaroslava, 2016, Milostné listy Karla Havlička a Fany Weidenhoffrové II. Kdo jsem já??, „Česká literatura”, nr 2, s 659-671.

$\mathrm{N}$ a g e 1 James, 1996, Brett and the Other Women in The Sun Also Rises, [w:] The Cambridge Companion to Ernest Hemingway, red. S. Donaldson, New York: Cambridge UP.

N ě m c o vá Božena, 2003-2007, Korespondence $I-I V$, red. R. Adam et al., Praha: NLN.

P a j a k Aleksandra, 2017, W objeciach Klio. Literackie reprezentacje wieku XIX we wspótczesnej prozie czeskiej, Opole: Wydawnictwo Uniwersytetu Opolskiego.

P i o r e c k ý Karel, 2016, Michal Šanda, [w:] Slovník české literatury po roce 1945. Online: http://www.slovnikceskeliteratury.cz/showContent.jsp?docId= 1620 \&hl=šanda + michal + [dostęp: 16.06.2016]

P o k o r n á Magdalena, 2016, Jedna hora vysoká je a druhýje nizká. Karel Havliček Borovský ve vzájemné korespondenčni a literární komunikaci, Praha: LN.

P o ř í z k o vá Lenka, 2014, Přátelský podvod. Mystifikace (nejen) v české literatuře 20. stoleti, Praha: Academia.

R y c h n o v s ká Lucie, A d a m Robert a kol., 2016, Karel Havliček ve svétle korespondence, Praha: NLN.

S k wa r c zy ń s k a Stefania, 2006 (1937), Teoria listu, opr. E. Feliksiak, M. Leś, Białystok: Wydawnictwo Uniwersytetu w Białymstoku.

Š a n d a Michal, 2018, Hemingwayưv býk. Hradec Králové: Paper Jam.

Tr z y n a d l o w s k i Jan, 1977, Mate formy literackie, Wrocław: Ossolineum. 